\title{
Study on the Influence of entrepreneurial failure Learning on Opportunity Recognition ability of Migrant Workers
}

\author{
Junli $\mathrm{Li}^{1, \mathrm{a}}$, Qin Chen ${ }^{* 1, \mathrm{~b}}$ (Corresponding author) \\ ${ }^{1}$ College of economics, Fujian Agriculture and Forestry University, Fuzhou, China
}

\begin{abstract}
Failure experiences induce entrepreneurs to reflect and learn, and help them accumulate entrepreneurial experience. This paper constructs a theoretical model of the influence of entrepreneurial learning on opportunity recognition ability under the failure situation, and through the questionnaire survey of 305 migrant workers entrepreneurs who have failed experience, it is found that entrepreneurial failure learning positively promotes opportunity recognition ability after failure.
\end{abstract}

\section{Introduction}

With the rising tide of "mass entrepreneurship and innovation" in China, a large number of migrant workers have been engaged in entrepreneurial activities one after another. However, the failure rate of migrant workers is high, and the survival and development of entrepreneurial enterprises are difficult. Migrant workers entrepreneurs are not afraid of failure, continuous entrepreneurship deserves attention. As an old Chinese saying goes, "Failure is the mother of success." Perhaps this is why Chinese entrepreneurs are not afraid of failure. By 2016, China's Labour force dynamic survey data found that after more than 2 times entrepreneurial experience of migrant workers accounted for $37.1 \%$, survey data on migrant workers found that after business failure, continue to choose the number of business accounted for $42.6 \%$ [1], so the "start up" study of migrant entrepreneurs are particularly important, after a failed, migrant entrepreneurs are learning how to failure? How does failure learning affect his ability to identify opportunities? Solving these problems is particularly important for promoting migrant workers to persist in entrepreneurship and developing rural economy.

With the increasing uncertainty and dynamics of the entrepreneurial environment, it is inevitable for entrepreneurs to encounter failures in the entrepreneurial process. Timely recovery from failures and effective learning from them are related to the survival and future development of subsequent entrepreneurial enterprises. At present, studies on entrepreneurship mainly focus on oneoff entrepreneurship [3], and pay less attention to entrepreneurs who have many entrepreneurial experiences. First-time entrepreneurs' behaviors may be somewhat accidental, and serial entrepreneurs are more likely to show some stable characteristics and have more research value under the influence of previous entrepreneurial experience[4]. The existing research on entrepreneurship focuses on the research on entrepreneurial success and ignores the research value of failure scenarios. Therefore, starting from the entrepreneurial failure itself, this paper studies the mechanism of entrepreneurial failure learning on opportunity identification ability, and then deduces how failure becomes a stepping stone to improve opportunity identification ability. Answering this question clearly is helpful to stimulate and protect entrepreneurs' entrepreneurial passion, improve the probability of entrepreneurial success, and promote continuous entrepreneurship.

\section{Study Design}

\subsection{Research Hypothesis}

Entrepreneurial failure stimulates entrepreneurs to reflect, innovate and explore, and enables them to re-examine the future entrepreneurial environment and their own ability and pursuit of value from a different perspective, which gradually becomes an important entry point for studying entrepreneurial learning behavior. Some scholars have proposed that entrepreneurial failure learning refers to the relatively lasting change of entrepreneurial behavior or behavioral potential obtained through entrepreneurial failure experience when entrepreneurs fail to achieve expected results. As for the current division of entrepreneurial learning modes, most scholars refer to the exploration of learning modes in the field of organizational learning indirectly mentioned the impact of failure on learning style[2][16]. The Luo mingzhong divided the entrepreneurial learning methods of farmers into two ways: exploratory learning and utilization learning[18]. This study adopts the classification method adopted by most scholars and divides the entrepreneurial failure learning methods of migrant workers into two dimensions: exploratory learning and utilization learning. Exploratory learning mainly brings new value through the study of novel information and technology, and utilization learning 
refers to the continuous use of current knowledge through full development, so as to realize the increase and expansion of value.

After encountering failure, entrepreneurs will have a more objective understanding of the difficulty of starting a business and make greater efforts in subsequent starting a business. Learning entrepreneurial failure helps entrepreneurs enrich entrepreneurial knowledge and relevant skills, and improve their ability to identify opportunities and evaluate opportunity values. Scholars believe that entrepreneurs' previous experience, such as industry experience, entrepreneurial experience, functional experience, has an impact on their ability to identify opportunities. Luo found that the entrepreneur's work experience affects the entrepreneur's ability to obtain and analyze information, thus affecting the entrepreneur's ability to identify opportunities[18].Zhang believe that working in various functional departments makes entrepreneurs more familiar with relevant management processes, more insightful, and easier to identify opportunities similar to previous jobs, thus improving their ability to identify opportunities[19]. Cai Li[20]found that entrepreneurial ability can bring entrepreneurs the most direct entrepreneurial information and knowledge, which is conducive to entrepreneurs' identification and acquisition of entrepreneurial opportunities, and has a significant impact on the formation and improvement of entrepreneurial ability.

Based on the theory of entrepreneurial process, entrepreneurs' thinking and decision-making process will change after their failure, especially their knowledge, thinking and ability[2]. Entrepreneurial failure cause entrepreneurs to update the entrepreneurial cognition, through reflection, failure of entrepreneurial learning, the ability to relate to promote new opportunities in the learning process and operation management ability, more objective evaluation and identification, use of entrepreneurial opportunities, more accurate interpretation of the new business environment, perfect entrepreneurial decision again[3], make it more matching with the external environment, improve the quality of decisions. Cognitive pattern and behavior directly determine their future development potential. After entrepreneurial failure, entrepreneurs can update their existing cognitive models by learning, reflecting, summarizing entrepreneurial failure experience, acquiring entrepreneurial knowledge[4][5] and improving their ability to identify opportunities. Therefore, based on the research of organizational learning theory, this paper uses exploratory learning and utilization learning to measure entrepreneurial learning, and puts forward the following hypothesis on the relationship between entrepreneurial failure learning and opportunity recognition ability.

H1: Entrepreneurship failure learning is positively correlated with opportunity recognition ability

H1a: Exploratory learning is positively correlated with opportunity recognition ability;

H1b: There is a positive correlation between exploitative learning and opportunity recognition ability.

To sum up, this study believes that different entrepreneurial learning styles help entrepreneurs to improve the ability of opportunity recognition. The conceptual model studied in this paper is shown in Figure 1.

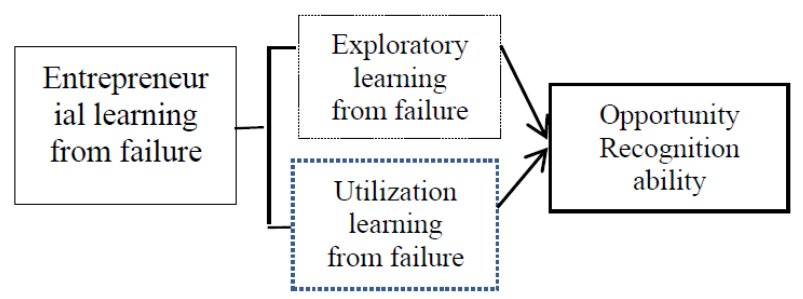

Fig1. Conceptual model

\subsection{Research samples and data collection}

The research object of this paper is limited to migrant workers who have entrepreneurial failure experience. From August to December 2019, a total of 481 questionnaires were collected, including 305 valid questionnaires. Through the analysis of 305 migrant workers entrepreneurs who have failed in starting a business, it is found that the proportion of male and female entrepreneurs is $62.5 \%$ and $37.5 \%$, the proportion of individuals under 30 years old is $32 \%$, the proportion of individuals between 30 and 35 years old is $36.5 \%$, and the proportion of those over 35 years old is $31.5 \%$. In terms of education level, the proportion of individuals in primary schools and below was 9.2\%; The proportion of individuals below junior high school is $39.1 \%$, and those above senior high school account for $51.7 \%$. The sample distribution is representative and random to a certain extent. Specific description is shown in Table 1 below.

\subsection{Variables and measurement}

(1) Business failure learning. This paper mainly refers to the failure learning style measurement scale in the organizational context, and at the same time, according to the interview contents of 8 entrepreneurs with entrepreneurial failure experience, the scale is improved. The scale consists of five questions, such as "After failure, I attach great importance to searching for new techniques, products and services that are different from the past". Exploitative learning such as "After failure, I search for information that will ensure continuous improvement in the efficiency and service of existing outputs".

(2) Opportunity identification ability. By referring to the existing maturity scale, and according to the interview of migrant workers entrepreneurs who have experienced failure, the scale is improved. Likert's 5-point scale was adopted to measure the scale, with 5 for very agreement and 1 for disagreement. Chance-related skills such as "the ability to perceive unmet needs in the marketplace;" "Can identify and evaluate market opportunities by means of investigation, training and learning from peers" "can capture the development trend of the industry;"

Table1. Descriptive statistical results of sample characteristics

\begin{tabular}{|c|c|c|c|}
\hline variable & category & The number & Percentage (\%) \\
\hline gender & male & 212 & $69.5 \%$ \\
\hline & female & 93 & $30.5 \%$ \\
\hline age & Under the age of 30, & 98 & $32.0 \%$ \\
\hline & $31-35$ years old & 111 & $36.5 \%$ \\
\hline
\end{tabular}




\begin{tabular}{|c|c|c|c|}
\hline & More than 35 years old & 96 & $31.5 \%$ \\
\hline $\begin{array}{c}\text { The degree } \\
\text { of } \\
\text { education }\end{array}$ & Junior College and below & 120 & $39.3 \%$ \\
\hline & Mniversity degree & 158 & $51.7 \%$ \\
\hline $\begin{array}{c}\text { Now the } \\
\text { establishm } \\
\text { ent of the } \\
\text { enterprise } \\
\text { time }\end{array}$ & $1-3$ years & 27 & $9.0 \%$ \\
\hline & 3 years and above & 88 & $71.2 \%$ \\
\hline $\begin{array}{c}\text { Current } \\
\text { enterprise } \\
\text { scale }\end{array}$ & small & 149 & $28.8 \%$ \\
\hline & Martial small & 115 & $48.9 \%$ \\
\hline $\begin{array}{c}\text { Time of } \\
\text { business } \\
\text { failure }\end{array}$ & The following 1 year & 86 & $37.8 \%$ \\
\hline & 1 to 2 years & 145 & $28.1 \%$ \\
\hline $\begin{array}{c}\text { Number of } \\
\text { entreprene } \\
\text { urship }\end{array}$ & 2 times & 74 & $47.6 \%$ \\
\hline & 3 times or more & 99 & $24.3 \%$ \\
\hline $\begin{array}{c}\text { Entreprene } \\
\text { urial } \\
\text { industry } \\
\text { transforma } \\
\text { tion }\end{array}$ & consistent & 208 & $67.5 \%$ \\
\hline & Don't agree & 97 & $32.5 \%$ \\
\hline
\end{tabular}

\section{The empirical analysis}

\subsection{Reliability and validity analysis}

First, reliability analysis was carried out on the five items of the entrepreneurial Failure Learning Scale. The results showed that Cronbach's coefficient was 0.784 , indicating that the data fitting results were good and the scale had good construction validity. Secondly, the reliability and validity analysis of the opportunity recognition ability scale was carried out. The results showed that Cronbach's coefficient was 0.873 , the factor load of each item was significant at the level of 0.01 , and the minimum value of the factor load of the opportunity-related ability was 0.622 , indicating that the scale had good structural validity.

\subsection{Correlation analysis}

As shown in Table 2 below, statistical results and correlation coefficients of all variables were described in this study. Among them, exploratory learning is significantly positively correlated with opportunity recognition ability, with a correlation coefficient of 0.518 . The two dimensions of exploratory learning and exploitative learning and opportunity recognition are significantly positively correlated.

Table2. Descriptive statistics and correlation analysis of variables

\begin{tabular}{|c|c|c|c|c|c|}
\hline variable & $\begin{array}{l}\text { The } \\
\text { mean }\end{array}$ & $\begin{array}{l}\text { The standard } \\
\text { deviation }\end{array}$ & 1 & 2 & 3 \\
\hline $\begin{array}{l}\text { Opportunity } \\
\text { recognition ability }\end{array}$ & 3.69 & 0.592 & 1 & & \\
\hline Exploratory learning & 3.688 & 0.56 & $0.518^{* *}$ & 1 & \\
\hline Utilization learning & 3.723 & 0.54 & $0.373^{* *}$ & $\begin{array}{l}0.36 \\
* \star\end{array}$ & 1 \\
\hline
\end{tabular}
same as below.

\subsection{Research hypothesis testing}

Entrepreneurial failure learning and opportunity recognition ability. This paper USES multiple linear regression model to analyze the relationship between entrepreneurial learning and entrepreneurial performance under the situation of failure. The analysis results show that there is a significant positive correlation between exploratory learning and utilization learning and opportunity recognition ability. The regression coefficients of 0.349 and 0.248 , respectively, $\mathrm{H} 1, \mathrm{H} 1 \mathrm{a}$ and $\mathrm{H} 1 \mathrm{~b}$ are supported. From the perspective of regression coefficient, exploratory failure learning has a greater effect on opportunity recognition ability.

Table3. Results of multiple linear regression

\begin{tabular}{|c|c|c|}
\hline variable & Model 1 & Model 2 \\
\hline gender & 0.068 & 0.068 \\
\hline age & 0.055 & 0.059 \\
\hline Education level & $0.142 *$ & 0.093 \\
\hline Time of establishment & 0.016 & 0.016 \\
\hline The enterprise scale & 0.082 & 0.017 \\
\hline Industry change & 0.073 & 0.045 \\
\hline Time of business failure & $0.146 *$ & $0.126 *$ \\
\hline Exploratory learning & & $0.349 * *$ \\
\hline Utilization learning & & $0.248 * *$ \\
\hline
\end{tabular}

\section{Research results}

The results show that the entrepreneurial failure learning of migrant workers can be divided into two dimensions: exploratory learning and utilization learning, and entrepreneurial failure learning has a significant positive impact on opportunity recognition ability. According to the survey results, entrepreneurs have a strong sense of failure learning. Through entrepreneurship failure learning, entrepreneurs have a great change in their cognition of industries, enterprises and their own advantages and disadvantages, and their opportunityrelated abilities have been greatly improved. At the same time, it is found that the two different failure learning methods have different mechanisms of action on reentrepreneurship performance.

After failure, migrant workers identify and analyze the causes of failure through utilizing learning, emphasize the modification or adjustment of original products and services, and help entrepreneurs extract the elements needed for success of re-entrepreneurship from existing failure experience, optimize their internal knowledge structure, and promote the improvement of opportunity identification ability[6]. The nature of leveraged learning is to refine and extend existing capabilities, techniques, and patterns, and its rewards are predictable. Exploratory learning, on the other hand, emphasizes the exploration of new possibilities. By summarizing failure experience, it constantly searches and learns externally, and introduces 
new and heterogeneous knowledge into the existing knowledge base of entrepreneurship, so as to promote the improvement of entrepreneurs' opportunity recognition ability. The nature of exploratory learning is experimentation with new solutions, and its rewards are uncertain.

\section{Acknowledgment}

This research was supported by science and technology innovation special fund project of Fujian Agriculture and Forestry University (CXZX2017414)

\section{References}

1. Liu xuan. Career change intention and influencing factors of those who fail to return home to start a business. Technical Economics and Management Research, 2019(10): 33-38.

2. Cope, J.Entrepreneurial Learning from Failure: An Interpretative phenomenological analysis [J]. Journal of Business Venturing, 2010,6 (2): 1-20.

3. Mitchell R K, Mitchell J R, Smith J B.Inside Opportunity formation: Enterprise failure, Cognition, and the creation of Opportunities [J].Strategic Entrepreneurship Journal, 2008,2 (3) : 225-242.

4. Starr J., By grave W.T he Assets and characterized of prior startup experience: An exploratory study of multiple venture entrepreneurs [M] / / Churchill N.C., et al. Frontiers of Entrepreneurship Research. Wellesley, MA: Babson College, 1991:213-227.

5. Ucbasaran D, Westhead P, Wright M. Habitual entrepreneurs experiencing failure, overconfidence and the motivation to try again // Wiklund J, Dimov D, Katz J A, et al. Advances in Entrepreneurship, Firm Emergence and Growth[M]. London: Emerald Group Publishing Limited, 2006.

6. Ucbasaran D, Westhead P, Wright M. The extent and nature of opportunity identification by experienced Entrepreneurs [J]. Journal of Business Venturing, 2009,24 (2):99-115.

7. Eggers J P, Song 1. Dealing with failure: Serial entrepreneurs and the costs of changing industries between ventures[J]. Academy of Management Journal, 2015,58(6):1785-1803.

8. Ucbasaran, D. Westhead, R., Wright, M., Floras, M.T he nature of entrepreneurial experience, business failure and comparative economics [J].Journal of Business Venturing, 2010, 25, 541-555.

9. Cardon M S, Stevens, C, E, Potter D r. Misfortunes or mistakes?Cultural sense making of entrepreneurial failure[J]. Journal of Business Venturing,2011,26(1):79-92.

10. Edwards J R, Lambert L S. Methods for integrating moderation and mediation: A general analytical frame work using moderated path analysis[J]. Psychological Methods, 2007, 12(1) : $1-22$.

11. Ayala J C, Manzano G. The resilience of the entrepreneur. Influence on the success of the business. A longitudinal analysis[J].Journal of Economic Psychology, 2014, 42: 126-135.

12. Bandura A. On deconstructing commentaries regarding alternative theories of self regulation[J]. Journal of Management, 2015, 41(4): 1025-1044.

13. Bullough A, Renko M. Entrepreneurial resilience during challenging times[J]. Business Horizons, 2013, 56(3): 343-350.

14. Bullough A, Renko M, Myatt T. Danger zone entrepreneurs: The importance of resilience and self-efficacy for entrepreneurial intentions $[\mathrm{J}]$. Entrepreneurship Theory and Practice, 2014, 38(3): 473-499.

15. Contreras F, De Dreu I, Espinosa J C. Examining the relationship between psychological capital and entrepreneurial intention: An exploratory study[J]. Asian Social Science, 2017, 13(3): 80-88.

16. Cope J. Entrepreneurial learning from failure: An interpretative phenomenological analysis[J]. Journal of Business Venturing, 2011, 26(6): 604-623.

17. Corner P D, Singh S, Pavlovich K. Entrepreneurial resilience and venture failure[J]. International Small Business Journal, 2017, 35(6): 687-708.

18. Luo Mingzhong, Chen Ming. Personality Traits, Entrepreneurial Learning and Entrepreneurial Performance of Farmers [J]. China Rural Economy,2014(10):62-75.

19. Zhang Xiu'e, Xu Xujiao, Entrepreneurial Learning, Entrepreneurial Alertedness and Farmers' Entrepreneurial Opportunity Identification -- an Intermediary Effect Model and its enlightenment. [J]. Commercial research, 2017,11:178-186.

20. CAI Li, TANG Shuqin, Ma Yanli, Gao Xiang. (in Chinese) Research on the Relationship between entrepreneurial learning, entrepreneurial ability and new Enterprise performance. [J]. Scientific research, 2014,32 (8): 1189-1197. 